\title{
Stay with Us, Crayfish and Let's Live Together a Long Time!
}

\author{
Kyung-chul, $\mathrm{Kim}^{1}$ and Eun hye, $\mathrm{Kim}^{2 *}$ \\ ${ }^{1}$ Professor, Department of Early Childhood Education, \\ Korea National University of Education \\ ${ }^{2}$ Doctor's course, Department of Early Childhood Education, \\ Korea National University of Education \\ ${ }^{1}$ kbrain@knue.ac.kr, ${ }^{2}$ grace-eh@daum.net
}

\begin{abstract}
The purpose of this study is to provide basic data for early childhood education in the forests by reviewing the process of the crayfish project in the forest kindergarten and the changes these young children went through as a result. The project was conducted with 21 four-to five-year-old children in the same class and their three teachers, for four weeks, from April 6 to May 1 of 2015. The project began with the discovery of a crayfish by the children in a small stream in the forest. In the developmental stage, young children examined the questions about crayfish through various activities. In the finishing stage, to protect the crayfish, the young children discussed the things they could do and practiced directly. The children found out that crayfishes had become an endangered species requiring conservation due to a sharp decrease in population because of environmental pollution. The children began to show their attitude to protect the crayfish and to protect it. Further, through the crayfish project, the children came to recognize that they are also beings living along with nature and to experience changes in their attitude toward (living with) nature.
\end{abstract}

Keywords: Early childhood education, Forest education, Project approach, Ecological community

\section{Introduction}

Today, serious environmental problems such as environmental pollution, abnormal climate, and resource depletion are emerging. Objects manufactured and discarded for the convenience of human beings are leading to the destruction of the habitats of animals and plants and threatening the survival of human beings. The extinction of flora and fauna has already reached a serious level due to such damage to the environment and ecosystems. The message about these dangers needs to be clearly conveyed. Carson[1] said that in the 20th century human beings had polluted air, soil, rivers and oceans, resulting in irreversible disasters.

Recently, our concept of "nature" has begun to change, from that of an object that human beings should look after and protect to that of a large community with(in) which human beings must also be in harmony. Accordingly, methods and lifestyles of living alongside nature, beyond simple environmental protection, are needed for the future society in which our children will live. Being able to implement and experience such methods, by which we can conserve the environment and also live as a part of nature rather than simply implementing an ambiguous and abstract concept of protecting nature, is being emphasized as very important educational content. In this regard, many scholars[2][3][4] emphasize the importance of loving nature from early childhood and educating interdependent relationships among all

Received (September 26, 2017), Review Result (January 12, 2018), Accepted (January 18, 2018) 
ecosystem members, including humans. This should ultimately lead to the realization of an ecological community. Accordingly, in early childhood education, there is a lot of interest in alternative programs that involve living alongside nature, such as nature-friendly education, ecological education, and forest education, and research on these is being actively conducted.

Nature is the best friend to young children and a source of learning. In particular, the valuable resources of the forest are enough to stimulate young children's curiosity and inspire them to continuously explore. Lee Myeong-hwan[5] stated that nature is a source of education that provides the best educational experience to young children, since the natural world itself is a repository of materials that can be directly experienced and manipulated. South Korea has an optimal environment for forest education, since $65 \%$ of the country is forestland. Young children can undergo holistic development, including physical, language, social, and emotional development, as they freely explore and interact with peers and nature in the forest, away from the confinement of their usual educational spaces and materials. In addition, they will develop an awe of everything alive through their interactions with living things in nature as they romp around in it[6].

Young children can understand the characteristics and growth processes of various animals and plants, and can recognize the diversity of ecosystems and the sanctity of life by meeting and exploring diverse living organisms in the forest. A variety of experiences in nature in early childhood are considered very important, since the attitude toward and knowledge of nature acquired in at a young age will greatly influence children's thinking later on. Early childhood is an important time for attitude formation, and in the same context is also an important time for environmental education[7]. Even 4 to 6 year olds have the ability to understand and think about environmental issues[8]. From early childhood to educating them to make responsible decisions with a sense of responsibility for a sustainable future is essential for a successful life as a member of the ecological community. Accordingly, the present study provides baseline data for early childhood nature educational interventions, by examining the progress of a crayfish project conducted in a forest environment with kindergarteners in South Korea and the changes these young children went through as a result.

The project was conducted with 21 four- to five-year-old children in the same class and their three teachers, for four weeks, from April 6 to May 1 of 2015. Their kindergarten is an everyday forest kindergarten, where project-integrated educational activities are carried out in the forest regardless of the weather, on topics involving materials easily found in the forest and season.

\section{Beginning of the Project: Meeting a Crayfish for the First Time}

\subsection{Here Is Something I See for the First Time!}

The project began with the discovery of a crayfish by the children in a small stream in the forest.

S: Teacher, here is something strange. I have never seen it before.

$P$ : Teacher, come quickly. There's something stuck under the rock here.

SB: Oh! Isn't this a crab? Here are some things that look like claws.

P: No, it looks different from a crab. It has a long tail here. Oh!! I know what it is. It looks similar to the lobster I ate in Thailand. Could it be a baby lobster?

(During a free play period, April 6, 2015) 


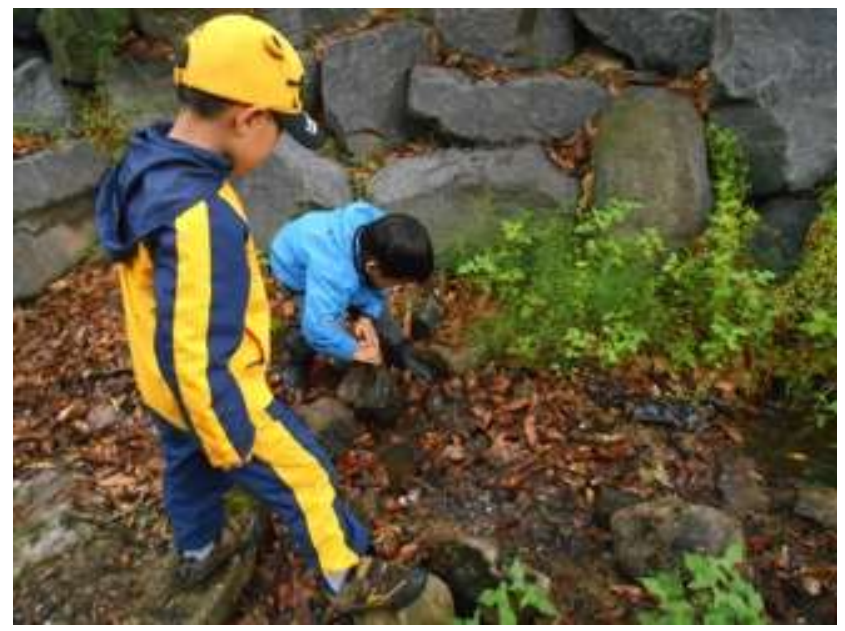

Figure 1. The Children Found a Crayfish Under a Rock in the Stream

\subsection{Crayfish, I Think It Is a Crayfish!}

(During the time set aside for discussing the project theme)

SB: We found a new animal in the small stream. I thought it was a crab, but my friends said it was not a crab.

P: It looks different from the crab I saw, but it looks similar to the lobster I had in Thailand.

$N$ : But, isn't a lobster really big? This one is small....

SB: Crayfish, I think it is a crayfish! So, I would like this to be the theme of our project.

(During story-telling, April 6, 2015)

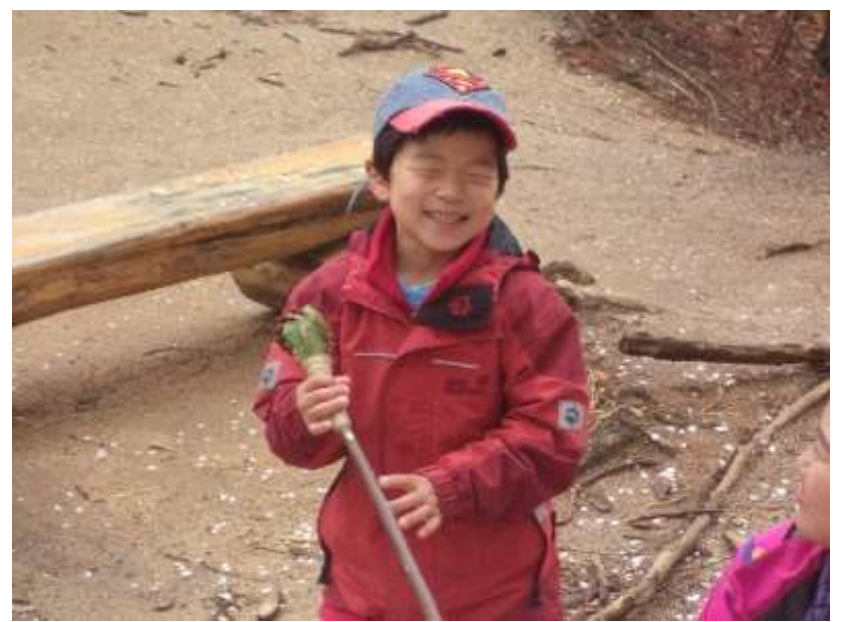

Figure 2. The Child Goes Forward and Tells His Opinion to His Friends

The children were very interested in the crayfish they encountered for the first time in the forest, and through discussions like those excerpted above, the children decided to carry out project activities on the subject of crayfish. The children made a list of questions about the crayfish and the teacher developed various activities with the children based on the list. 


\section{Deployment of the Project}

\subsection{Want to Know More about Crayfish}

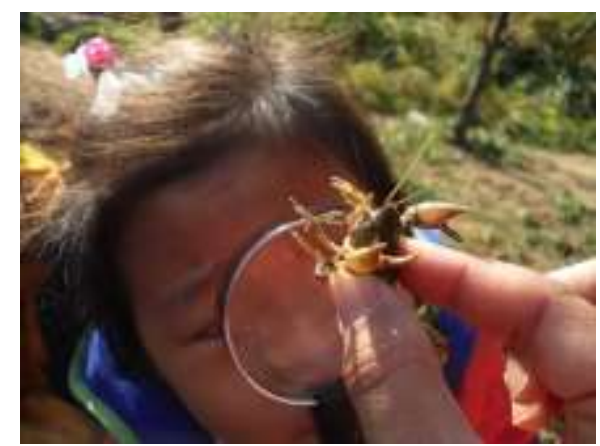

Figure 3. A Child Is Closely Observing A Crayfish With A Magnifying Glass

\section{What does a crayfish look like?}

The children were most curious about the appearance of the crayfish, and wanted to closely observe it. They observed the crayfish through a magnifying glass and examined its appearance. They compared it to a crab, discussing similarities and differences.

NY: These claws are really cute. By the way, how many legs are there? One, two, three, four ... six in all.

YC: The claws are legs too. I will count the claws too.

NY: Right, right. (The two were looking at each other and laughing)

(During the observation of the crayfish, April 7, 2015)
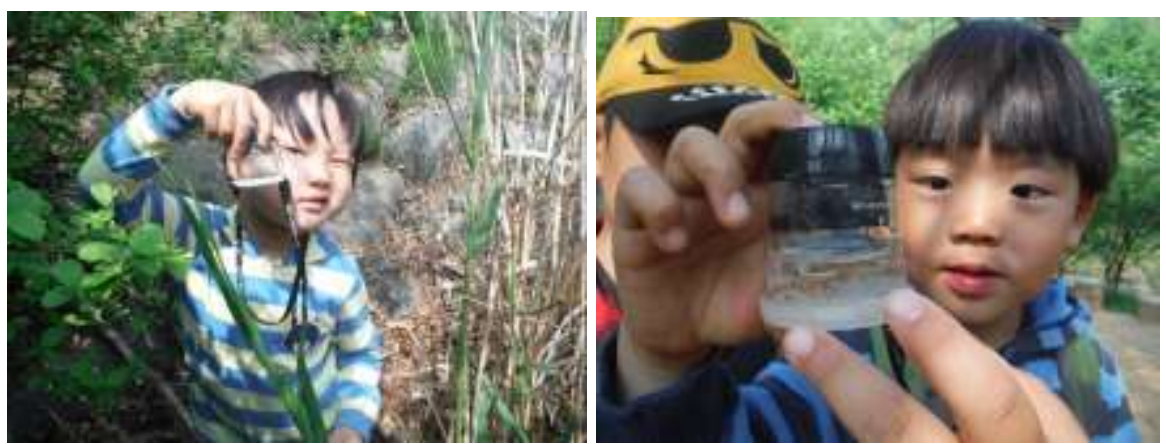

Figure 4. 5. The Children are observing the Crayfish through the Loupe

\section{What does a crayfish eat?}

The children explored the food of the crayfish by playing a "find food for crayfish" game. In the game, the children wore crayfish headbands to transform themselves into crayfish and searched for the food the crayfish eats, which was hidden all over a stream in the forest. They learned that crayfish eat small fish or floating objects through the game. 

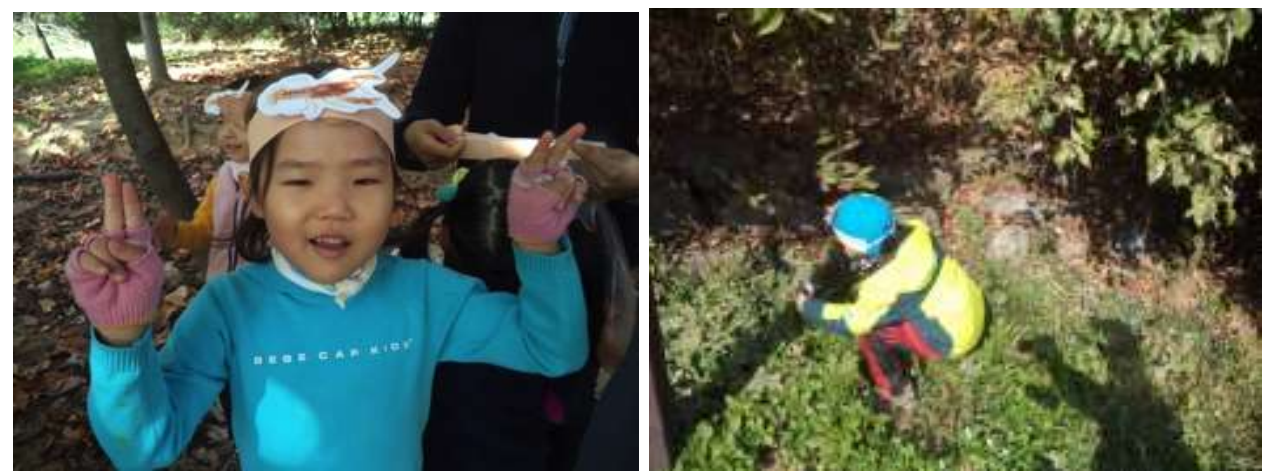

Figure 6. 7. A Child Is Searching for the Food of the Crayfish Hidden In the Stream While Wearing a Crayfish Headband and Making Her Fingers Look Like the Claws of a Crayfish

\subsection{The Crayfish Is Disappearing}

SB: Teacher, I really like the crayfish. Look here. Isn't it really cute to see them wriggling around?

SH: By the way, why didn't we find the crayfish before? There are a lot of frogs. I really saw a crayfish for the first time here.

SB: Yeah, me too.

(During a free play period, April 14, 2015)

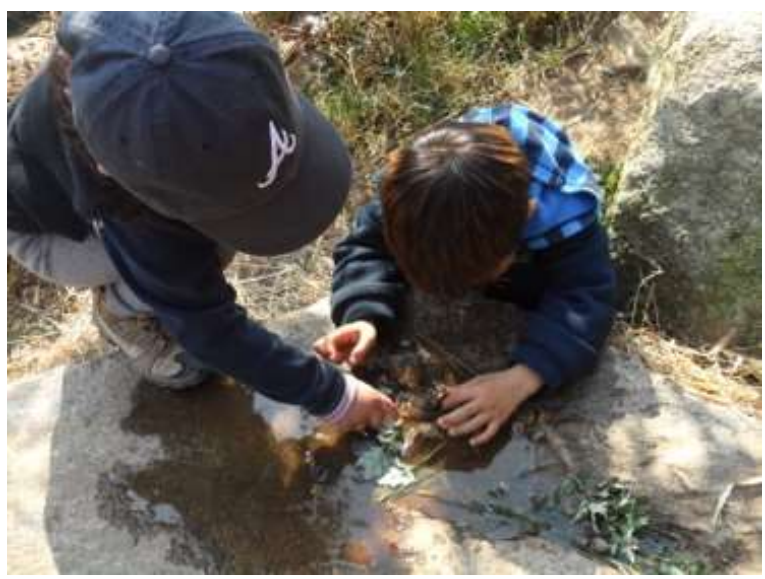

Figure 8. The Children Are Watching and Talking About the Crayfish

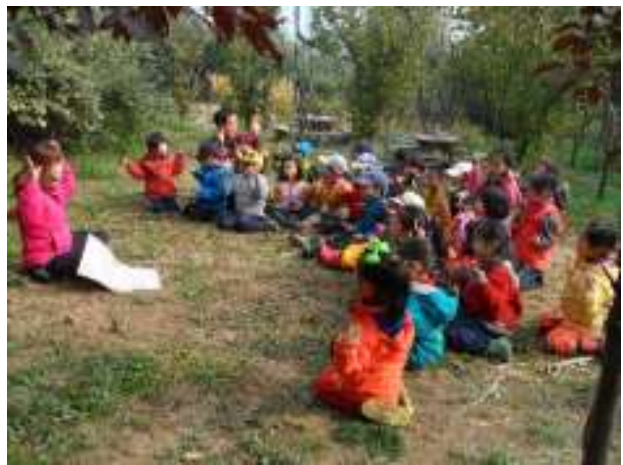

Figure 9. The Children are Singing With the Teacher

The children learned the song "Finding the Lobster" with the teacher. 
T: Where crystal clear water flows

A: Teacher, What is crystal clear water?

T: What is crystal clear water? What do you think?

BJ: Totally clean water? So crayfish can live in a clean place like a crystal?

GY: Ah! I know! Then the water is not crystal clear, so crayfish cannot live. The water is so dirty.

(At the time of learning a new song, April 16, 2015)

While observing and talking about the crayfish during free play time, the children were wondering why the crayfish had not been easily found before then, and they explored the reasons with the teacher. The children found out that crayfishes can only live in uncontaminated grade 1 water of rivers and streams, and that they had become an endangered species requiring conservation due to a sharp decrease in population because of environmental pollution.

\subsection{Let Us Protect the Crayfish!}

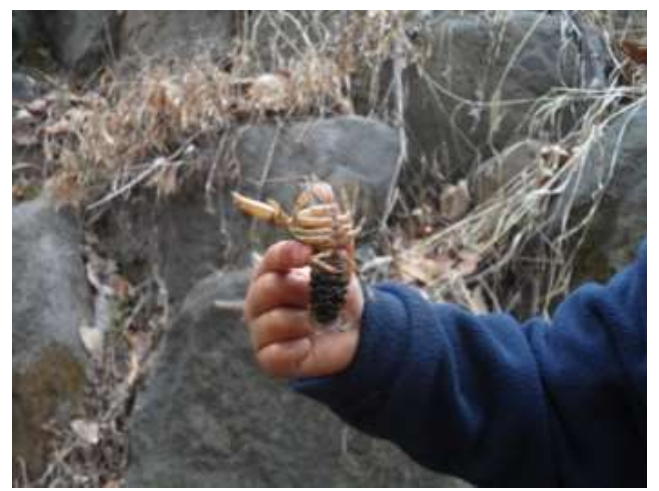

Figure 10. There Are Eggs on the Belly of the Crayfish the Children Found

SH: Look here! There's something strange stuck on the belly of the crayfish here!

SB: Oh! A pregnant crayfish. Let her go fast. We have to protect the pregnant crayfish. Don't let her get stressed! Let's carefully put her under the rock.

EJ: I'm sorry, crayfish. Take a good care of the eggs and hatch lots and lots of baby crayfishes. So that you don't disappear from the Earth. Do you understand?

(During free play, April 17, 2015)

MS: Teacher, I want to put some grass where the crayfish is.

T: why did you think of that?

MS: I want to make shade for the crayfish because there is too much sunshine here. I think it would be difficult for the crayfish if it gets too hot. And I want the crayfish to eat this grass when she is hungry.

(During free play, April 22, 2015) 

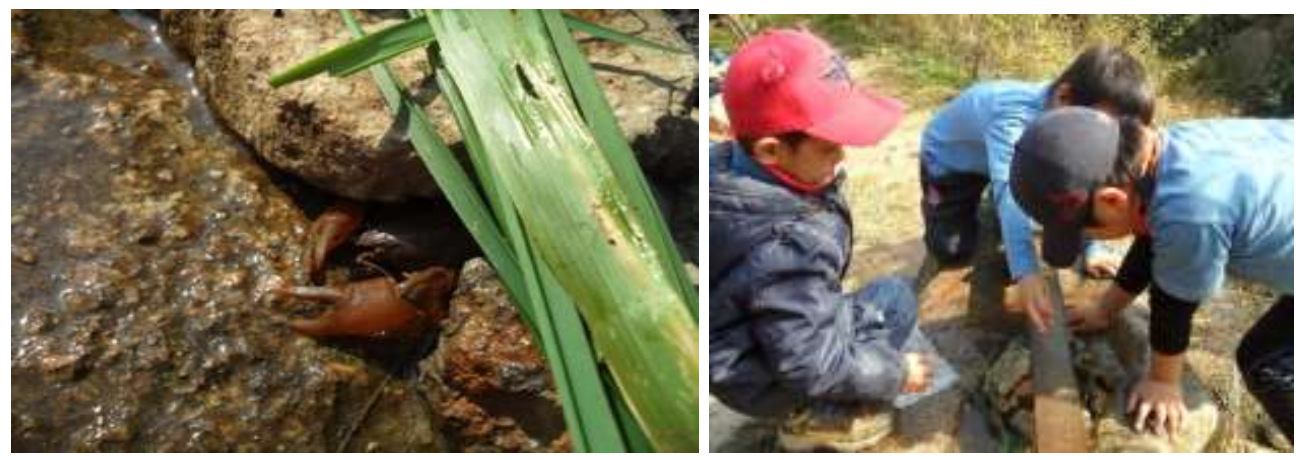

\section{Figure 11. 12. The Children Put Some Grass on the Rock Where the Crayfish is}

The children learned that crayfishes are gradually disappearing due to environmental pollution and began to show the attitude that cherishing and protecting the crayfish was important.

\section{Finishing the Project: Let's Clean the Forest}

\subsection{How Can We Protect the Crayfish?}

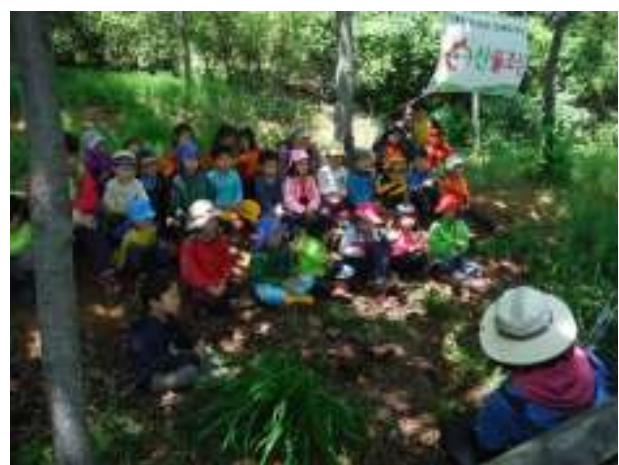

Figure 13. The Children Are Sharing Ideas with the Teacher on How to Protect the Crayfish

HY: Teacher, then how can we make the crayfish continue to be with us?

T: What can we do?

NK: Well. You said crayfishes can only live in very clean water. So, if we make the water clean, I think the crayfish can live well.

T: Then how can we make the water clean?

SH: Teacher, I saw a man passing by and throwing garbage over there. If they throw away the garbage like that, the place where the crayfish lives will get dirty.

SB: Oh! Teacher, I have a good idea. Then let's pick up the trash ourselves.

(During story-telling, April 27, 2015)

The children agreed to keep the stream clean to protect the disappearing crayfish, and decided to organize a cleanup campaign, setting a cleaning day to pick up trash in the forest 

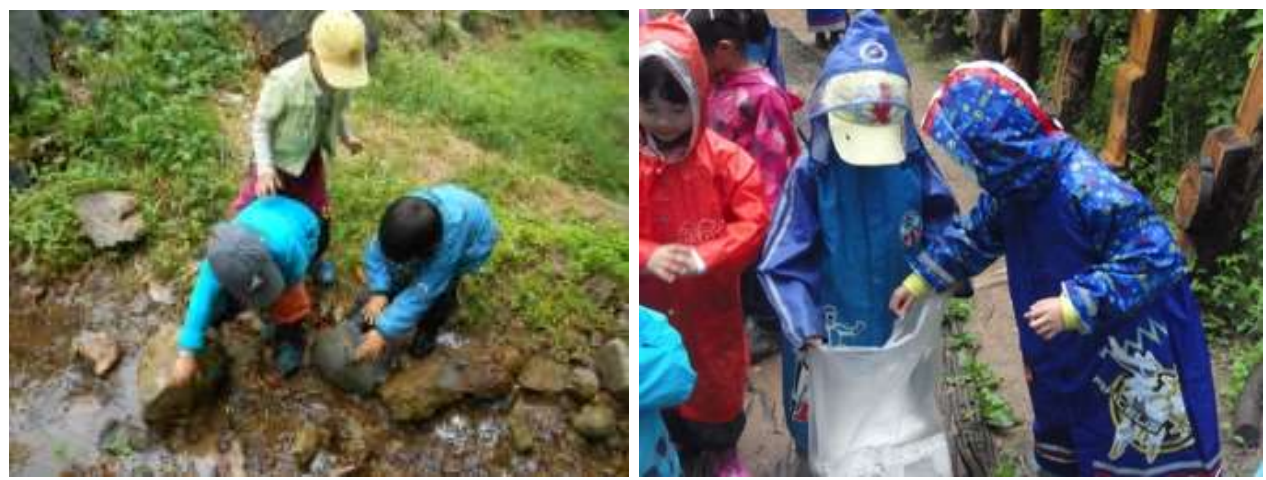

\section{Figure 14. Children Are Putting Garbage in a Garbage Bag during the Forest Clean-Up Campaign}

The children made the "protect the crayfish" flyer for the campaign themselves. They walked around the forest with trash bags to collect trash, and handed out their flyer to passing mountain climbers, asking them to help make the forest where the crayfish lives clean.

\section{Epilogue to the Project: Stay with Us, Crayfish, and Let's Live Together a Long Time!}

Through the crayfish project children developed a friendly attitude toward the crayfish and came to understand that it too is a being with a precious life and subjectivity. In addition, the children came to feel sorry about the reality that precious forms of life are disappearing due to environmental contamination. After that, they thought about what they could do to protect those lifeforms and put their ideas into practice on their own initiative. In the process, the children organically experienced and came to understand the principle of nature that the ecosystem functions as a community. These results confirm the importance of experiencing nature directly. This is in agreement with the assertion that an emotional bond with nature based on direct experience must be formed in order for children of Wilson, Kilmer \& Knauerhase[9] to have healthy environmental awareness. Fenton[10] also said that if you want to educate children to take good care of the environment in the same context, they should first let you experience nature in a familiar way, and to "fall in love with nature". In the present study, children were more affectionate to certain natural objects, and they were able to understand ecological relations.

Further, through the crayfish project, the children came to recognize that they are also beings living along with nature and to experience changes in their attitude toward (living with) nature. It is expected that they will be able to grow into members of a new generation whose practices are devoted to authentic coexistence between human beings and nature, rather than simply protecting and preserving the environment.

\section{Acknowledgments}

This paper is a revised and expanded version of a paper entitled [Let's protect precious crayfishes!] presented at [International Conferences AST 2017, Hanoi, Vietnam, February 9-12, 2017]. 


\section{References}

[1] R. L. Carson, "Silence Spring”, Ecolives, Seoul, (2002).

[2] O. S. Yang, "Early childhood education through nature", Children's Education Association 20th Anniversary Celebration for Early Childhood Education, (2001), pp. 43-60.

[3] H. Y. Wi, "A Theological Study on the Relation of the Nature Ecosystem and Human Being", Korea Journal of Christian Studies, vol.30, (2003), pp.343-363.

[4] E. J. Yun, "Zur Uberlegung uber die Christliche Erziehung als Okologische Bildung", Korea Journal of Christian Studies, vol.30, (2003), pp.477-501.

[5] L. Myeong-Hwan, "Model of nature-friendly early childhood education German forest kindergarten", Education academy, Seoul, (2007).

[6] R. A. Wilson, "Nature and young children: a natural connection”, Young Children, vol.50, no.6, (1995), pp.4-11.

[7] D. Tilbury, "The international development of environmental education: a basis for a teacher education model?" Environmental education and information, vol.13, no.1, (1994), pp.1-20.

[8] J. Palmer, , "Research matters: a call for the application of empirical evidence to the task of improving the quality and impact of environmental education", Cambridge journal of education, vol.29, no.3, (1999), pp.513-527.

[9] R. A. Wilson, S. Kilmer and V. Knaueerhase, "Developing as environmental outdoor play space", Young Children, vol.50, no.6, (1996), pp.4-11.

[10] G. M. Fenton, "Back to our roots in nature's classroom”, Young Children, vol.50, no.3, (1996), pp.8-11.

[11] K.-C. Kim and E.H. Kim, "Let's protect precious crayfishes!", Proceedings of the International Conferences AST 2017, Hanoi, Vietnam, (2017).

\section{Authors}

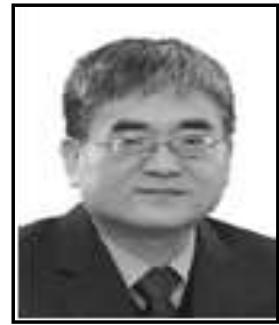

Kyung-chul, Kim, he is a Professor, Department of Early Childhood Education, Korea National University of Education.

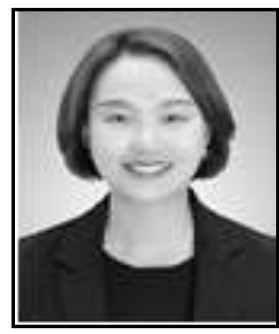

Eun-hye, Kim, she has a Doctor's course, Department of Early Childhood Education, Korea National University of Education. 
International Journal of Advanced Science and Technology

Vol.110 (2018) 